\title{
Ocean acidification over the next three centuries using a simple global climate carbon-cycle model: projections and sensitivities
}

\author{
Corinne A. Hartin, Benjamin Bond-Lamberty, Pralit Patel, and Anupriya Mundra \\ Pacific Northwest National Laboratory, Joint Global Change Research Institute at the University \\ of Maryland-College Park, 5825 University Research Court \#3500, College Park, MD 20740, USA \\ Correspondence to: C. A. Hartin (corinne.hartin@pnnl.gov)
}

Received: 15 October 2015 - Published in Biogeosciences Discuss.: 4 December 2015

Revised: 30 June 2016 - Accepted: 7 July 2016 - Published: 1 August 2016

\begin{abstract}
Continued oceanic uptake of anthropogenic $\mathrm{CO}_{2}$ is projected to significantly alter the chemistry of the upper oceans over the next three centuries, with potentially serious consequences for marine ecosystems. Relatively few models have the capability to make projections of ocean acidification, limiting our ability to assess the impacts and probabilities of ocean changes. In this study we examine the ability of Hector v1.1, a reduced-form global model, to project changes in the upper ocean carbonate system over the next three centuries, and quantify the model's sensitivity to parametric inputs. Hector is run under prescribed emission pathways from the Representative Concentration Pathways (RCPs) and compared to both observations and a suite of Coupled Model Intercomparison (CMIP5) model outputs. Current observations confirm that ocean acidification is already taking place, and CMIP5 models project significant changes occurring to 2300. Hector is consistent with the observational record within both the high- $\left(>55^{\circ}\right)$ and low-latitude oceans $\left(<55^{\circ}\right)$. The model projects low-latitude surface ocean $\mathrm{pH}$ to decrease from preindustrial levels of 8.17 to 7.77 in 2100 , and to 7.50 in 2300 ; aragonite saturation levels $\left(\Omega_{\mathrm{Ar}}\right)$ decrease from 4.1 units to 2.2 in 2100 and 1.4 in 2300 under RCP 8.5. These magnitudes and trends of ocean acidification within Hector are largely consistent with the CMIP5 model outputs, although we identify some small biases within Hector's carbonate system. Of the parameters tested, changes in $\left[\mathrm{H}^{+}\right]$are most sensitive to parameters that directly affect atmospheric $\mathrm{CO}_{2}$ concentrations $-Q_{10}$ (terrestrial respiration temperature response) as well as changes in ocean circulation, while changes in $\Omega_{\mathrm{Ar}}$ saturation levels are sensitive to changes in ocean salinity and $Q_{10}$. We conclude that Hector is a robust tool well suited for rapid ocean acidification projections and
\end{abstract}

sensitivity analyses, and it is capable of emulating both current observations and large-scale climate models under multiple emission pathways.

\section{Introduction}

Human activities have led to increasing anthropogenic emissions of greenhouse gases to the atmosphere. In the first decade of the 21 st century $\mathrm{CO}_{2}$ emissions from anthropogenic sources and land-use changes accounted for $\sim 9 \mathrm{PgC} \mathrm{yr}^{-1}$, with future emission projections of up to $28 \mathrm{PgC} \mathrm{yr}^{-1}$ by 2100 under Representative Concentration Pathway (RCP) 8.5 (Riahi et al., 2011). The world's oceans have played a critical role in lessening the effects of climate change by absorbing $25-30 \%$ of the total anthropogenic carbon emissions since 1750 (Le Quéré et al., 2013; Sabine et al., 2011).

In response to this increasing atmospheric burden of $\mathrm{CO}_{2}$ and increasing oceanic uptake, the oceans are experiencing both physical and biogeochemical changes: surface and deep water warming, reduced subsurface oxygen, and a reduction in calcium carbonate saturation levels and $\mathrm{pH}$ (Doney, 2010). Mean surface ocean $\mathrm{pH}$ has already decreased by 0.1 units relative to preindustrial times (Caldeira et al., 2003). If current emission trends continue, ocean acidification will occur at rates and extents not observed over the last few million years (Feely et al., 2004, 2009; Kump et al., 2009; Caldeira et al., 2003). Ocean acidification occurs when atmospheric $\mathrm{CO}_{2}$ dissolves in seawater $\left(\mathrm{CO}_{2}(\mathrm{aq})\right)$, forming carbonic acid $\left(\mathrm{H}_{2} \mathrm{CO}_{3}\right)$, dissociating into carbonate $\left(\mathrm{CO}_{3}^{2-}\right)$ and bicarbonate $\left(\mathrm{HCO}_{3}^{-}\right)$, and releasing protons $\left(\mathrm{H}^{+}\right)$. The 
net effect of adding $\mathrm{CO}_{2}$ to the system increases the concentrations of $\left[\mathrm{H}_{2} \mathrm{CO}_{3}\right],\left[\mathrm{HCO}_{3}^{-}\right]$, and $\left[\mathrm{H}^{+}\right]$, while decreasing $\left[\mathrm{CO}_{3}^{2-}\right]$ concentrations and lowering the $\mathrm{pH}$. The sum of $\left[\mathrm{HCO}_{3}^{-}\right],\left[\mathrm{CO}_{3}^{2-}\right]$, and $\left[\mathrm{CO}_{2}^{*}\right]$, where $\left[\mathrm{CO}_{2}^{*}\right]=\left[\mathrm{CO}_{2}(\mathrm{aq})\right]$ $+\left[\mathrm{H}_{2} \mathrm{CO}_{3}\right]$ represents the dissolved inorganic (DIC) of the system. As $\mathrm{CO}_{2}(\mathrm{aq})$ continues to increase in the ocean it reacts with $\mathrm{CO}_{3}^{2-}$, forming $\mathrm{HCO}_{3}^{-}$, decreasing the fraction of $\mathrm{CO}_{2}$ that can be readily absorbed by the oceans. Because of this capacity of the ocean to buffer chemical changes, a doubling of atmospheric $\left[\mathrm{CO}_{2}\right]$ will not correspond to a doubling of $\left[\mathrm{CO}_{2}^{*}\right]$ but instead will result in an increase on the order of $10 \%$ (Dickson and Millero, 1987). Due to both chemical and physical changes (e.g., warming and stratification), the oceans may become less efficient in the uptake of anthropogenic $\mathrm{CO}_{2}$ as the climate continues to change (Sarmiento and Le Quéré, 1996; Matear and Hirst, 1999; Joos et al., 1999; Le Quéré et al., 2010).

Numerous experiments and observations indicate that ocean acidification will have significant effects on calcifying marine organisms. For example, the rate of coral reef building may decrease, calcification rates of planktonic cocolithophores and foraminifera may be suppressed, and significant changes in trophic-level interactions and ecosystems may occur (Cooley and Doney, 2009; Silverman et al., 2009; Fabry et al., 2008; Riebesell et al., 2000). Some coral reefs are believed to already be eroding for parts of the year due to ocean acidification (Yates and Halley, 2006; Albright et al., 2013). Global surface $\mathrm{pH}$ is projected to drop by up to 0.33 units (Gehlen et al., 2014; Orr et al., 2005) and all existing coral reefs will be surrounded by conditions well outside of preindustrial values and even today's saturation levels (Ricke et al., 2013) under the RCP 8.5 scenario.

These model projections of ocean acidification come primarily from Earth system models (ESMs) that integrate the interactions of atmosphere, ocean, land, ice, and biosphere to estimate the present and future state of the climate. ESMs are computationally expensive and typically run using stylized experiments or a few RCPs (greenhouse gas concentration trajectories used in the Intergovernmental Panel on Climate Change 5th Assessment Report; IPCC, 2013). This generally limits ESM-based analyses to those scenarios. The occurrence of ocean warming and acidification is consistent across CMIP5 ESMs, but their rates and magnitudes are strongly dependent upon the scenario (Bopp et al., 2013).

An alternative to ESMs are reduced-form models, relatively simple and small models that can be powerful tools due to their simple input requirements, computational efficiency, tractability, and thus ability to run multiple simulations under arbitrary future emission pathways. This allows for the quantification of arbitrary climate change scenarios, emulation of larger ESMs, and in-depth parameter sensitivity studies and uncertainty analyses (Senior and Mitchell, 2000; Ricciuto et al., 2008; Irvine et al., 2012).
Our goal of this study is to quantify how well Hector, a reduced-form model that explicitly treats surface ocean chemistry, emulates the marine carbonate system of both observations and the CMIP5 archive, as well as to explore the parametric sensitivities to Hector's ocean outputs. The remainder of the paper is organized as follows: Sect. 2 gives a detailed description of Hector's ocean component, the data sources, and simulations run; Sect. 3 presents results of the model comparison and sensitivity experiments; and, lastly, Sect. 4 discusses the results.

\section{Model description - Hector}

Hector is open-source and available at https://github.com/ JGCRI/hector. The repository includes all model code needed to compile and run the model, as well as all input files and R scripts to process its output. Hector is a reducedform climate carbon-cycle model which takes in emissions of $\mathrm{CO}_{2}$ and non- $\mathrm{CO}_{2}$ (e.g., $\mathrm{CH}_{4}, \mathrm{~N}_{2} \mathrm{O}$ and halocarbons, and aerosols), converts emissions to concentrations where needed, and calculates the global radiative forcing and then global mean temperature change. Hector contains a wellmixed global atmosphere; a land component consisting of vegetation, detritus, and soil; and an ocean component. In this study we use Hector v1.1, with an updated ocean temperature algorithm, to better match the CMIP5 mean. For a detailed description of the land and atmospheric components of Hector, please refer to Appendix A and Hartin et al. (2015).

\subsection{Ocean component}

Hector's ocean component is based on work by Lenton (2000), Knox and McElroy (1984), and Sarmiento and Toggweiler (1984). It consists of four boxes: two surface boxes (high and low latitude) and one intermediate and one deep box. The cold high-latitude surface box makes up $15 \%$ of the ocean surface area, representing the subpolar gyres $\left(>55^{\circ}\right)$, while the warm low-latitude surface box $\left(<55^{\circ}\right)$ makes up $85 \%$ of the ocean surface area. The temperatures of the surface boxes are linearly related to the global atmospheric temperature change and are initialized at $2{ }^{\circ} \mathrm{C}$ and $22^{\circ} \mathrm{C}$ for the high- and low-latitude boxes, respectively. This temperature gradient sets up a flux of carbon into the cold high-latitude box and a flux out of the warm low-latitude box. The ocean-atmosphere flux of carbon is the sum of all the surface fluxes $\left(F_{i}, n=2\right)$.

$F_{O}(t)=\sum_{i=1}^{n} F_{i}(t)$

Once carbon enters the high-latitude surface box it is circulated between the boxes via advection and water mass exchange, simulating a simple thermohaline circulation. In this version of Hector we do not explicitly model diffusion; simple box-diffusion models and "HILDA" (e.g., Siegenthaler 
and Joos, 1992) type models are typically in good agreement with observations but are more computationally demanding than a simple box model (Lenton, 2000). The change in carbon of any ocean box $i$ is given by the fluxes in and out $(j)$ with $F_{\text {atm } \rightarrow i}$ as the atmospheric carbon flux of the two surface boxes:

$\frac{\mathrm{dC}_{i}}{\mathrm{~d} t}=\sum_{j=1}^{\text {in }} F_{j \rightarrow i}-\sum_{j=1}^{\text {out }} F_{i \rightarrow j}+F_{\mathrm{atm} \rightarrow i}$.

The flux of carbon between the boxes is related to the transport $\left(T_{i \rightarrow j}, \mathrm{~m}^{3} \mathrm{~s}^{-1}\right)$ between $i$ and $j$, the volume of $i\left(V_{i}\right.$, $\mathrm{m}^{3}$ ), and the total carbon in $i$ (including any air-sea fluxes) $\left(\mathrm{C}_{i}, \mathrm{Pg} \mathrm{C}\right)$ :

$\frac{\mathrm{dC}_{i \rightarrow j}}{\mathrm{~d} t}=\frac{T_{i \rightarrow j} \times \mathrm{C}_{i}(t)}{V_{i}}$.

Volume transports are tuned to yield an approximate flow of $100 \mathrm{Pg} \mathrm{C}$ from the surface high-latitude box to the deep ocean box at steady state, simulating deep water formation.

Hector calculates DIC, total alkalinity (TA), $\mathrm{CO}_{3}^{2-}, \mathrm{HCO}_{3}^{-}$ $p \mathrm{CO}_{2}$, and $\mathrm{pH}$. DIC and TA are the two carbonate variables used to solve the rest of the carbonate system. The detailed carbonate chemistry equations are based on numeric programs from Zeebe and Wolf-Gladrow (2001) (Appendix B). We simplified the equations by neglecting the effects of pressure, since we are only concerned with the surface ocean. Hector is run to equilibrium in a perturbation-free mode, prior to running the historical period, ensuring that it is in steady state (Hartin et al., 2015; Pietsch and Hasenauer, 2006). DIC ( $\mu \mathrm{mol} \mathrm{kg}^{-1}$ ) in the surface boxes is a function of the total carbon $(\mathrm{PgC})$ and the volume of the box. All carbon within the ocean component is assumed to be inorganic carbon. Dissolved organic matter is less than $2 \%$ of the total inorganic carbon pool, of which a small fraction is dissolved organic carbon (Hansell and Carlson, 2001), and particulate organic carbon is less than $1 \%$ of the total carbon pool (Eglinton and Repeta, 2004). Therefore, for simplicity we chose not to include dissolved or particulate organic carbon within Hector.

TA is calculated at the end of model spinup (running to equilibrium in a historical, perturbation-free mode) and held constant throughout the run, resulting in $2311.0 \mu \mathrm{mol} \mathrm{kg}-1$ for the high-latitude box and $2435.0 \mu \mathrm{mol} \mathrm{kg}^{-1}$ for the lowlatitude box. These values are within the range of openocean observations of $2250.0-2450.0 \mu \mathrm{mol} \mathrm{kg}^{-1}$ (Key et al., 2004; Fry et al., 2015). We assume negligible carbonate precipitation/dissolution and no alkalinity runoff from the land surface to the open ocean. Alkalinity is typically held constant with time, which is a reasonable assumption over several thousand years (Lenton, 2000; Zeebe and WolfGladrow, 2001; Glotter et al., 2014; Archer et al., 2009). On glacial-interglacial timescales, alkalinity and the dissolution of $\mathrm{CaCO}_{3}$ sediments are important factors in controlling atmospheric $\left[\mathrm{CO}_{2}\right]$ (Sarmiento and Gruber, 2006), and thus, on these scales, Hector will underestimate the oceanic $\mathrm{CO}_{2}$ uptake.

Hector solves for $p \mathrm{CO}_{2}, \mathrm{pH}$ (total scale), $\left[\mathrm{HCO}_{3}^{-}\right]$, $\left[\mathrm{CO}_{3}^{2-}\right]$, and aragonite $\left(\Omega_{\mathrm{Ar}}\right)$ and calcite saturation states $\left(\Omega_{\mathrm{Ca}}\right)$ in both the high- and low-latitude surface ocean boxes. $p \mathrm{CO}_{2}$ is calculated from the concentration of $\left[\mathrm{CO}_{2}^{*}\right]$ and the solubility of $\mathrm{CO}_{2}$ in seawater, based on salinity and temperature. $\left[\mathrm{CO}_{2}^{*}\right]$ is calculated from DIC and the first and second dissociation constants of carbonic acid from Mehrbach et al. (1973), refit by Lueker et al. (2000) (Appendix B).

Carbon fluxes between the atmosphere and ocean are calculated with (Takahashi et al., 2009)

$F=k \alpha \times \Delta p \mathrm{CO}_{2}=\operatorname{Tr} \times \Delta p \mathrm{CO}_{2}$,

where $k$ is the $\mathrm{CO}_{2}$ gas-transfer velocity, $\alpha$ is the solubility of $\mathrm{CO}_{2}$ in seawater $\left(\mathrm{K}_{0}\right.$, Appendix $\left.\mathrm{B}\right)$, and the $\Delta p \mathrm{CO}_{2}$ is the difference in $p \mathrm{CO}_{2}$ between the atmosphere and ocean. The product of $k$ and $\alpha$ results in $\mathrm{Tr}$, the sea-air gas-transfer coefficient, where $\operatorname{Tr}\left(\mathrm{g} \mathrm{C} \mathrm{m}^{-2}\right.$ month $\left.^{-1} \mu \mathrm{atm}^{-1}\right)=0.585 \times \alpha \times S c^{-1 / 2} \times U_{10}^{2}$ 0.585 is a unit conversion factor (from mol L$~^{-1} \mathrm{~atm}^{-1}$ to $\mathrm{g}$ $\mathrm{C} \mathrm{m}^{-3} \mu \mathrm{atm}^{-1}$ and from $\mathrm{cm} \mathrm{h}^{-1}$ to $\mathrm{mmonth}^{-1}$ ) and $S c$ is the Schmidt number. The Schmidt number (Appendix B) is calculated from Wanninkhof (1992) based on the temperature of each surface box. The average wind speed $\left(U_{10}\right)$ of $6.7 \mathrm{~m} \mathrm{~s}^{-1}$ is the same over both surface boxes (Table 1). $\mathrm{pH}$ (total scale), $\left[\mathrm{HCO}_{3}^{-}\right]$, and $\left[\mathrm{CO}_{3}^{2-}\right]$ are calculated using the $\left[\mathrm{H}^{+}\right]$ion and solved for in a higher-order polynomial (Appendix B).

Aragonite and calcite are the two primary carbonate minerals within seawater. The degree of saturation in seawater with respect to aragonite $\left(\Omega_{\mathrm{Ar}}\right)$ and calcite $\left(\Omega_{\mathrm{Ca}}\right)$ is calculated from the product of the concentrations of calcium $\left[\mathrm{Ca}^{2+}\right]$ and carbonate ions $\left[\mathrm{CO}_{3}^{2-}\right]$, divided by the solubility product $\left(\mathrm{K}_{\mathrm{sp}}\right)$. The $\left[\mathrm{Ca}^{2+}\right]$ is based on equations from Riley and Tongudai (1967) at a constant salinity of 34.5. If $\Omega=1$, the solution is at equilibrium, and if $\Omega>1(\Omega<1)$, the solution is supersaturated (undersaturated) with respect to the mineral.

$\Omega=\frac{\left[\mathrm{Ca}^{2+}\right]\left[\mathrm{CO}_{3}^{2-}\right]}{\mathrm{K}_{\mathrm{sp}}}$

\subsection{Simulation and experiments}

Hector is run under prescribed emissions from 1850 to 2300 for all four RCPs (RCP 2.6, RCP 4.5, RCP 6, RCP 8.5; Moss et al., 2010; van Vuuren et al., 2007). We compare how well Hector can emulate the carbonate system of the CMIP5 median. Our results section will mainly focus on RCP 8.5 ex- 
Table 1. Description and values of ocean parameters in Hector and parameters involved in the sensitivity analysis. High and low latitude are indicated as HL and LL.

\begin{tabular}{|c|c|c|}
\hline Description & Value & Notes \\
\hline Albedo $\mathrm{a}, \mathrm{b}$ & $-0.2 \mathrm{Wm}^{-2}$ & Constant global albedo from 1950 to 2300 \\
\hline Area of ocean & $3.6 \times 10^{14} \mathrm{~m}^{2}$ & Knox and McElroy (1984) \\
\hline Beta $^{\mathrm{a}, \mathrm{b}}$ & 0.36 & Terrestrial $\mathrm{CO}_{2}$ fertilization Wullschleger et al. (1995) \\
\hline Climate sensitivity ${ }^{\mathrm{a}, \mathrm{b}}$ & $3.0^{\circ} \mathrm{C}$ & \\
\hline Fractional area of $\mathrm{HL}$ & 0.15 & Sarmiento and Toggweiler (1984) \\
\hline Fractional area of LL & 0.85 & Sarmiento and Toggweiler (1984) \\
\hline$Q_{10}^{\mathrm{a}, \mathrm{b}}$ & 2.0 & $\begin{array}{l}\text { Terrestrial respiration temperature } \\
\text { response Davidson and Janssens (2006) }\end{array}$ \\
\hline Thickness of surface ocean & $100 \mathrm{~m}$ & Knox and McElroy (1984) \\
\hline Thickness of intermediate ocean & $900 \mathrm{~m}$ & \\
\hline Thickness of deep ocean & $2677 \mathrm{~m}$ & Total ocean depth $3777 \mathrm{~m}$ \\
\hline Volume of HL & $5.4 \times 10^{15} \mathrm{~m}^{3}$ & \\
\hline Volume of LL & $3.06 \times 10^{16} \mathrm{~m}^{3}$ & \\
\hline Volume of IO & $3.24 \times 10^{17} \mathrm{~m}^{3}$ & \\
\hline Volume of DO & $9.64 \times 10^{17} \mathrm{~m}^{3}$ & \\
\hline Surface area of HL & $5.4 \times 10^{13} \mathrm{~m}^{2}$ & \\
\hline Surface area of LL & $3.06 \times 10^{14} \mathrm{~m}^{2}$ & \\
\hline Salinity $\mathrm{HL}$ and $\mathrm{LL}^{\mathrm{b}}$ & 34.5 & \\
\hline Initial temperature of $\mathrm{HL}^{\mathrm{b}}$ & $2.0^{\circ} \mathrm{C}$ & \\
\hline Initial temperature of $\mathrm{LL}^{\mathrm{b}}$ & $22.0^{\circ} \mathrm{C}$ & \\
\hline Thermohaline circulation $\left(T_{\mathrm{T}}\right)^{\mathrm{a}, \mathrm{b}}$ & $7.2 \times 10^{7} \mathrm{~m}^{3} \mathrm{~s}^{-1}$ & Tuned to give $\sim 100 \mathrm{Pg} \mathrm{C}$ flux from surface to deep \\
\hline High-latitude circulation $\left(T_{\mathrm{H}}\right)^{\mathrm{a}}$ & $4.9 \times 10^{7} \mathrm{~m}^{3} \mathrm{~s}^{-1}$ & Tuned to give $\sim 100 \mathrm{Pg} \mathrm{C}$ flux from surface to deep \\
\hline Water mass exchange (intermediate to deep $\left.-E_{\mathrm{ID}}\right)^{\mathrm{a}}$ & $1.25 \times 10^{7} \mathrm{~m}^{3} \mathrm{~s}^{-1}$ & Lenton (2000), Knox and McElroy (1984) \\
\hline Water mass exchange (low latitude to intermediate $\left.-E_{\mathrm{IL}}\right)^{\mathrm{a}}$ & $2.08 \times 10^{7} \mathrm{~m}^{3} \mathrm{~s}^{-1}$ & Lenton (2000), Knox and McElroy (1984) \\
\hline Wind speed HL and $\mathrm{LL}^{\mathrm{b}}$ & $6.7 \mathrm{~m} \mathrm{~s}^{-1}$ & Takahashi et al. (2009), Liss and Merlivat (1986) \\
\hline
\end{tabular}

${ }^{\mathrm{a}}$ Parameters contained within the input file. ${ }^{\mathrm{b}}$ Parameters varied for the sensitivity analysis.

ploring the response of the carbonate system under a highemissions scenario.

We also ran a series of model sensitivity experiments to quantify how influential some of Hector's parameter inputs are on its outputs (in particular, $\left[\mathrm{H}^{+}\right]$and $\Omega_{\mathrm{Ar}}$ ). Such sensitivity analyses are important to document model characteristics, explore model weaknesses, and determine to what degree the model behavior conforms to our existing understanding of the ocean system. We do not sample Hector's entire parameter space, a computationally demanding exercise, but instead choose a list of the parameters that we expect, a priori, to be important in calculating the marine carbonate system. We selected those parameters directly influencing atmospheric $\mathrm{CO}_{2}$ concentrations (beta and $Q_{10}$ ), parameters involved in the calculation of temperature (albedo and climate sensitivity), and those parameters involved in the uptake of carbon in the surface ocean (ocean surface temperature, salinity, wind stress, and ocean circulation). These parameters are varied by $\pm 10 \%$ relative to the RCP 8.5 control, and we compare the percentage change from the reference and the perturbation cases in 2005, 2100, and 2300. The reference, RCP 8.5, refers to the tuned set of parameters found in Hector v1.1, resulting in Figs. 2-6.

\subsection{Data sources}

All RCP input emission data are available at http://tntcat. iiasa.ac.at/RcpDb/. Comparison data are obtained from a suite of CMIP5 ESMs (Table 2; Taylor et al., 2012). The CMIP5 output is available from the Program for Climate Model Diagnostics and Intercomparison (http://pcmdi3.llnl. gov/esgcet/home.htm). We took the $0-100 \mathrm{~m}$ (depth) mean for all available CMIP5 data for six output variables, computing the monthly mean for all years in the historical (18502005) and RCP 8.5 (2006-2300) experiments. All outputs were regridded to a standard $1^{\circ}$ grid using bilinear interpolation in CDO version 1.7.1 $\mathrm{rc} 1$, and then high-latitude $(-90$ to -55 and 55 to $90^{\circ}$ ), low latitude ( -55 to 55 ), and global area-weighted means computed using R 3.2.4. All CMIP5 comparisons used in this study are from model runs with prescribed atmospheric $\mathrm{CO}_{2}$ concentrations. We acknowledge that this is not a perfect comparison as Hector is emissionsforced, compared to the concentration-forced CMIP5 models, but very few of the latter were run under prescribed emissions. We use a combination of root mean square error (RMSE), rates of change $(\Delta)$, and bias (degree of systematic over- or underestimation) to characterize Hector's performance relative to the CMIP5 median. 


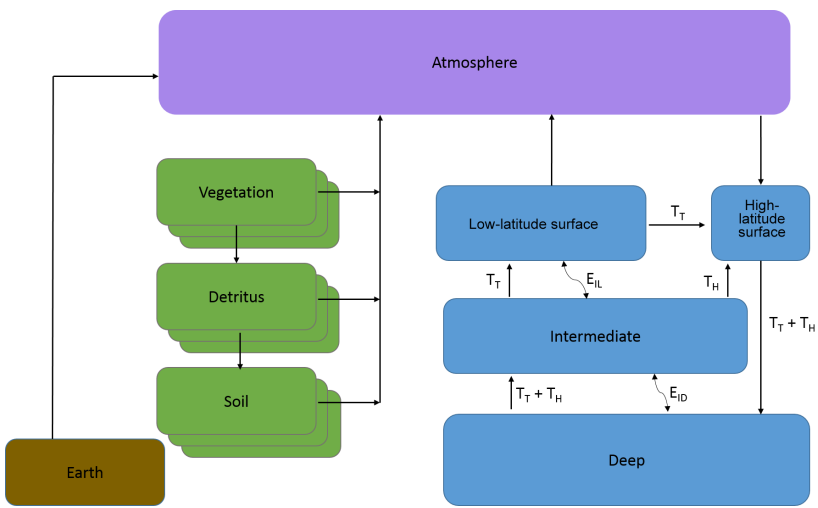

Figure 1. Representation of the carbon cycle in Hector. The atmosphere consists of one well-mixed box, connected to the surface ocean via air-sea fluxes of carbon. The terrestrial component consists of user defined biomes or regions for vegetation, detritus, and soil. The earth pool is continually debited to act as a mass-balance check on the carbon cycle (Hartin et al., 2015). The ocean consists of four boxes, with advection (represented by straight arrows) and water mass exchange (represented by curved arrows) simulating thermohaline circulation. The marine carbonate system is solved for in the high- and low-latitude surface boxes. At steady state, there is a flux of carbon from the atmosphere to the high-latitude surface box, while the low-latitude surface ocean releases carbon to the atmosphere.

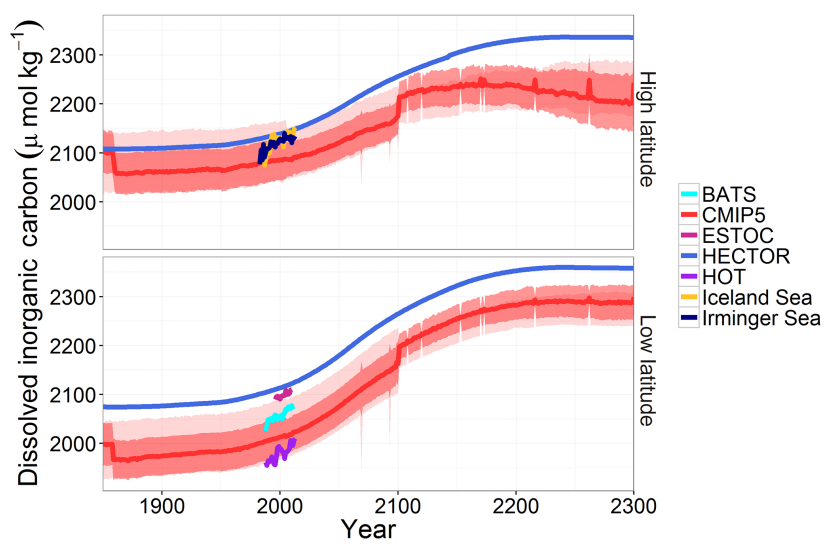

Figure 2. Dissolved inorganic carbon (DIC) for high- (top) and low-latitude (bottom) surface ocean under RCP 8.5: Hector (blue), CMIP5 median, standard deviation, and model range (red, $n=15$ (1850-2100, with $n=4$ starting after 1860) and $n=3 ; 2101-2300)$, as well as observations from BATS (teal), ESTOC (pink), HOT (purple), Iceland Sea (yellow), and Irminger Sea (navy). Note that a doubling of $\mathrm{CO}_{2}$ from preindustrial values occurs around 2050.

We also compare Hector to a series of observational ocean data. Surface ocean observations of DIC, $p \mathrm{CO}_{2}, \mathrm{pH}, \Omega_{\mathrm{Ar}}$, and $\Omega_{\mathrm{Ca}}$ are from time-series stations in both the highand low-latitude oceans: Hawaii Ocean Time Series (HOT), Bermuda Atlantic Time Series (BATS), the European Station for Time Series in the Ocean at the Canary Islands (ESTOC),
Table 2. CMIP5 ESMs used in this study containing ocean carbonate parameters. $\Omega_{\mathrm{Ar}}$ and $\Omega_{\mathrm{Ca}}$ were calculated from the model sea surface temperature, sea surface salinity, and $\mathrm{CO}_{3}$ concentrations.

\begin{tabular}{|c|c|}
\hline Model & Parameters (RCP 8.5) \\
\hline BCC-cm1-1 & $p \mathrm{CO}_{2}^{*}$, temperature \\
\hline BNU-ESM & $p \mathrm{CO}_{2}$ \\
\hline CanESM2 & DIC, $\mathrm{pH}$, salinity \\
\hline CESM1-BGC & $\mathrm{CO}_{3}, \mathrm{DIC}, \mathrm{pH}$, salinity \\
\hline CMCC-CESM & $\begin{array}{l}p \mathrm{CO}_{2} \text {, temperature, } \mathrm{CO}_{3} \text {, } \\
\text { DIC, } \mathrm{pH} \text {, salinity }\end{array}$ \\
\hline CNRM-CM5 & $\mathrm{CO}_{3}, \mathrm{DIC}$ \\
\hline GFDL-ESM2G & $p \mathrm{CO}_{2}$, temperature, $\mathrm{pH}$, salinity \\
\hline GFDL-ESM2M & $\begin{array}{l}p \mathrm{CO}_{2} \text {, temperature, } \mathrm{CO}_{3} \\
\text { pH, DIC, salinity }\end{array}$ \\
\hline GISS-E2-H-CC & $p \mathrm{CO}_{2}$, temperature, DIC, salinity \\
\hline GISS-E2-R-CC & $p \mathrm{CO}_{2}$, temperature, DIC, salinity \\
\hline HadGEM2-CC & $\begin{array}{l}p \mathrm{CO}_{2} \text {, temperature, } \mathrm{CO}_{3} \\
\text { DIC, } \mathrm{pH}, \text { salinity }\end{array}$ \\
\hline HadGEM2-ES & $\begin{array}{l}p \mathrm{CO}_{2}, \text { temperature, } \mathrm{CO}_{3}^{*} \\
\mathrm{DIC}^{*}, \mathrm{pH}, \text { salinity }\end{array}$ \\
\hline IPSL-CM5A-LR & $\begin{array}{l}\text { Temperature* } \mathrm{CO}_{3}^{*}, \mathrm{DIC}^{*} \\
\mathrm{pH}^{*}, \text { salinity* }\end{array}$ \\
\hline IPSL-CM5A-MR & Temperature, $\mathrm{CO}_{3}$, DIC, $\mathrm{pH}$, salinity \\
\hline IPSL-CM5B-LR & Temperature, $\mathrm{CO}_{3}$, DIC, $\mathrm{pH}$, salinity \\
\hline MIROC-ESM & $p \mathrm{CO}_{2}$, temperature, salinity \\
\hline MIROC-ESM-CHEM & $p \mathrm{CO}_{2}$, temperature, salinity \\
\hline MPI-ESM-LR & $\begin{array}{l}p \mathrm{CO}_{2}^{*}, \text { temperature* }, \mathrm{CO}_{3}^{*} \\
\mathrm{DIC}^{*}, \mathrm{pH}^{*}, \text { salinity* }\end{array}$ \\
\hline MPI-ESM-MR & $\begin{array}{l}p \mathrm{CO}_{2}, \text { temperature, } \mathrm{CO}_{3} \\
\text { DIC, } \mathrm{pH} \text {, salinity }\end{array}$ \\
\hline MRI-ESM1 & $p \mathrm{CO}_{2}$, temperature \\
\hline NorESM1-ME & $\begin{array}{l}p \mathrm{CO}_{2} \text {, temperature, } \mathrm{CO}_{3} \text {, } \\
\text { DIC, } \mathrm{pH} \text {, salinity }\end{array}$ \\
\hline
\end{tabular}

* Variable output to 2300

the Irminger Sea, and the Iceland Sea (Table 3). The timeseries data are annually averaged over the upper $100 \mathrm{~m}$ of the water column. The carbonate parameters not found in Table 3 are computed from temperature, salinity, and the given carbonate parameter pairs using the CO2SYS software (Lewis and Wallace, 1998). The equilibrium constants (K1 and K2 from Mehrbach et al., 1973, refit by Dickson and Millero, 1987) and zero total phosphorus and silica were chosen to best match Hector. Lastly, a longer record (1708-1988) of $\mathrm{pH}$ and $\Omega_{\mathrm{Ar}}$ from Flinders Reef in the western Coral Sea, calculated from boron isotope measurements, is used in the comparison (Pelejero et al., 2005). We use rates of change $(\Delta)$ from 1988 to 2014, which overlaps the HOT and BATS time series, to quantify how well Hector simulates the observed changes in the ocean carbonate parameters (Table 6; Dore et al., 2009; Bates et al., 2014). 
Table 3. Observational time-series information and carbonate parameters from each location.

\begin{tabular}{llllll}
\hline Time-series site & Location & Time-series length & Reference & Ocean carbon parameters & Data access \\
\hline BATS & Sargasso Sea & $1988-2011$ & Bates (2007) & TA, DIC & http://www.bios.edu/research/projects/bats \\
HOT & North Pacific & $1988-2011$ & Dore et al. (2009) & TA, DIC, pH, $p$ CO ${ }_{2}$, & http://hahana.soest.hawaii.edu/hot/hot_jgofs.html \\
& & & & $\Omega_{\mathrm{Ar}, \Omega_{\mathrm{Ca}}}$ \\
ESTOC & Canary Islands & $1995-2009$ & Gonález-Dávila et al. (2007) & $\mathrm{TA}, \mathrm{pH}, p \mathrm{CO}_{2}$ & http://www.eurosites.info/estoc.php \\
Iceland Sea & Iceland Sea & $1985-2013$ & Olafsson et al. (2009) & DIC, $p \mathrm{CO}_{2}$ & http://cdiac.ornl.gov/oceans/Moorings/Iceland_Sea.html \\
Irminger Sea & Irminger Sea & $1983-2013$ & Olafsson et al. (20010) & DIC, $p \mathrm{CO}_{2}$ & http://cdiac.ornl.gov/oceans/Moorings/Irminger_Sea.html \\
Flinders Reef & Coral Sea & $1708-1988$ & Pelejero et al. (2005) & $\mathrm{pH}, \Omega_{\mathrm{Ar}}$ & ftp://ftp.ncdc.noaa.gov/pub/data/paleo/coral/ \\
\hline
\end{tabular}

Table 4. Model validation metrics for the (a) high-latitude and (b) low-latitude ocean carbonate variables in the comparison of Hector to CMIP5 from 1850 to 2005.

\begin{tabular}{lrrr}
\hline (a) & RMSE & $\mathrm{R} 2$ & Bias \\
\hline $\mathrm{DIC}$ & 10.00 & 0.26 & 47.10 \\
$p \mathrm{CO}_{2}$ & 2.65 & 0.98 & -31.78 \\
$\mathrm{pH}$ & 0.004 & 0.975 & 0.061 \\
$\Omega_{\mathrm{Ar}}$ & 0.01 & 0.98 & 0.37 \\
$\Omega_{\mathrm{Ca}}$ & 0.02 & 0.98 & 0.58 \\
\hline$(\mathbf{b})$ & $\mathrm{RMSE}$ & $\mathrm{R} 2$ & $\mathrm{Bias}$ \\
\hline $\mathrm{DIC}$ & 6.50 & 0.76 & 101.28 \\
$p \mathrm{CO} 2$ & 3.43 & 0.98 & -4.62 \\
$\mathrm{pH}$ & 0.004 & 0.966 & 0.025 \\
$\Omega_{\mathrm{Ar}}$ & 0.02 & 0.97 & 0.36 \\
$\Omega_{\mathrm{Ca}}$ & 0.03 & 0.97 & 0.53 \\
\hline
\end{tabular}

\section{Results}

\subsection{Model and observation comparisons}

Hartin et al. (2015) conducted a thorough analysis of Hector v1.0, demonstrating that it can reproduce the historical trends and future projections of atmospheric $\left[\mathrm{CO}_{2}\right]$, radiative forcing, and global temperature change under the four RCPs. In this study we focus on the upper ocean high- and low-latitude inorganic carbon chemistry under RCP 8.5.

Hector captures the trend in DIC concentrations for both the high- and low-latitude surface ocean with a global RMSE average of $7.0 \mu \mathrm{mol} \mathrm{kg}-1$ when compared to CMIP5 models over the historical period (Table 4; Fig. 2). We note that there is a systematic bias in both the high- and low-latitude surface boxes when compared to CMIP5. First, the carbon pools of the surface boxes are initialized with carbon values slightly higher than the median CMIP5 values. Second, after 2100 the high-latitude CMIP5 median begins to decline, while Hector rises and stabilizes. Only three CMIP5 models ran out to 2300, with one model driving the decline. Regardless, this offset only results in a $<3 \%$ global difference between CMIP5 and Hector.

Hector accurately tracks the $p \mathrm{CO}_{2}$ in both the high- and low-latitude surface ocean with similar rates of change from 1850 to 2300 (Fig. 3). There is a low bias in Hector compared

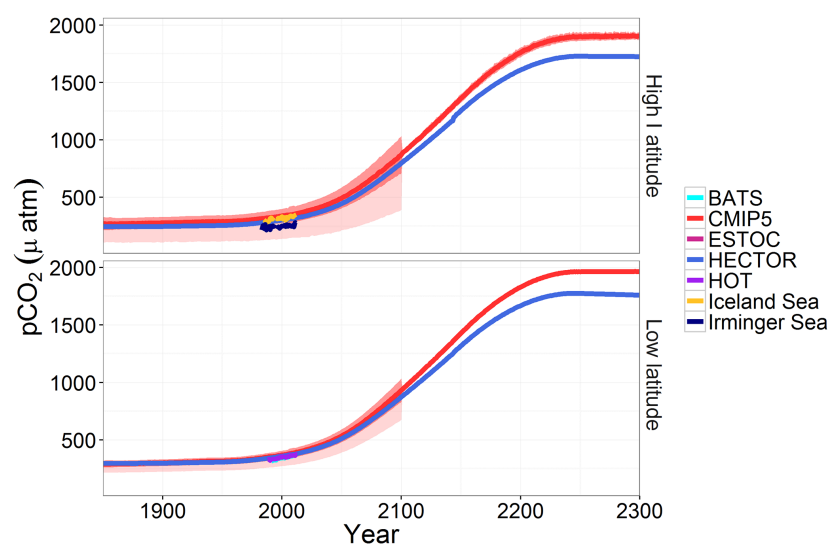

Figure 3. $p \mathrm{CO}_{2}$ for high- (top) and low-latitude (bottom) surface ocean under RCP 8.5: Hector (blue), CMIP5 median, standard deviation, and model range (red, $n=5(1850-2100)$ and $n=2 ; 2101-$ 2300), as well as observations from BATS (teal), HOT (purple), ESTOC (pink), Iceland Sea (yellow), and Irminger Sea (navy).

to CMIP5 models after 2100, due to the low bias in projected atmospheric $\left[\mathrm{CO}_{2}\right]$ within Hector over the same time period (Hartin et al., 2015). We find Hector to be in closer agreement with the observation record.

Figure 4 shows the high- and low-latitude surface $\mathrm{pH}$ of Hector compared to CMIP5 and observations from BATS, HOT, ESTOC, Irminger Sea, Iceland Sea, and Flinders Reef. While the high-latitude surface $\mathrm{pH}$ is slightly higher than the CMIP5 models, Hector is more similar to high-latitude observations. Since the preindustrial, observations of surface ocean $\mathrm{pH}$ decreased by 0.08 units, corresponding to a $24 \%$ increase in $\left[\mathrm{H}^{+}\right]$concentrations and an $8 \%$ decrease in $\left[\mathrm{CO}_{3}^{2-}\right]$, similar to numerous studies (Feely et al., 2004; Sabine et al., 2004; Caldeira et al., 2003; Orr et al., 2005) that estimate an average global decrease in $\mathrm{pH}$ of 0.1 or a $30 \%$ increase in $\left[\mathrm{H}^{+}\right]$.

The Flinders Reef $\mathrm{pH}$ record provides a natural baseline to compare future trends in ocean acidification. While we did not expect the model to match exactly, as this reef site is heavily influenced by coastal dynamics and internal variability, rates of change from the preindustrial (1750) to 1988 are the same $\left(0.0002 \mathrm{yr}^{-1}\right)$ for both Hector and Flinders Reef. Over the limited observational record from both the Pacific and Atlantic oceans, Hector accurately simulates the decline 
Table 5. Absolute values and rates of change per year $(\Delta)$ for the (a) high- and (b) low-latitude surface ocean from 1850 to 2100 and 2101 to 2300 under RCP 8.5 for DIC ( $\mu \mathrm{mol} \mathrm{kg}{ }^{-1}$ ), $p \mathrm{CO}_{2}$ ( $\mu \mathrm{atm}$ ), $\mathrm{pH}$ (total scale, unitless), $\Omega_{\mathrm{Ar}}$ (unitless), and $\Omega_{\mathrm{Ca}}$ (unitless).

\begin{tabular}{|c|c|c|c|c|c|c|c|c|c|c|c|c|c|c|c|}
\hline \multirow[t]{2}{*}{ (a) } & \multicolumn{3}{|c|}{ DIC } & \multicolumn{3}{|c|}{$p \mathrm{CO} 2$} & \multicolumn{3}{|c|}{$\mathrm{pH}$} & \multicolumn{3}{|c|}{$\Omega_{\mathrm{Ar}}$} & \multicolumn{3}{|c|}{$\Omega_{\mathrm{Ca}}$} \\
\hline & 1850 & 2100 & 2300 & 1850 & 2100 & 2300 & 1850 & 2100 & 2300 & 1850 & 2100 & 2300 & 1850 & 2100 & 2300 \\
\hline $\begin{array}{l}\text { Hector } \\
\Delta\end{array}$ & 2107.5 & $\begin{array}{r}2258.1 \\
0.602\end{array}$ & $\begin{array}{r}2335.5 \\
0.387\end{array}$ & 244.7 & $\begin{array}{r}816.6 \\
2.29\end{array}$ & $\begin{array}{r}1732.1 \\
4.58\end{array}$ & 8.23 & $\begin{array}{r}7.76 \\
-0.0019\end{array}$ & $\begin{array}{r}7.46 \\
-0.0015\end{array}$ & 2.2 & $\begin{array}{r}1.0 \\
-0.0048\end{array}$ & $\begin{array}{r}0.6 \\
-0.002\end{array}$ & 3.5 & $\begin{array}{r}1.5 \\
-0.008\end{array}$ & $\begin{array}{r}0.9 \\
-0.003\end{array}$ \\
\hline $\begin{array}{l}\text { CMIP5 } \\
\Delta\end{array}$ & 2104.50 & $\begin{array}{r}2175.79 \\
0.285\end{array}$ & $\begin{array}{r}2243.41 \\
0.34\end{array}$ & 271.62 & $\begin{array}{r}871.00 \\
2.40\end{array}$ & $\begin{array}{r}1903.82 \\
5.16\end{array}$ & 8.17 & $\begin{array}{r}7.70 \\
-0.0019\end{array}$ & $\begin{array}{r}7.38 \\
-0.0016\end{array}$ & 1.82 & $\begin{array}{r}0.75 \\
-0.0012\end{array}$ & $\begin{array}{r}0.44 \\
-0.0016\end{array}$ & 2.90 & $\begin{array}{r}1.20 \\
-0.0068\end{array}$ & $\begin{array}{r}0.70 \\
-0.0025\end{array}$ \\
\hline (b) & & DIC & & & $p \mathrm{CO} 2$ & & & $\mathrm{pH}$ & & & $\Omega_{\mathrm{Ar}}$ & & & $\Omega_{\mathrm{Ca}}$ & \\
\hline & 1850 & 2100 & 2300 & 1850 & 2100 & 2300 & 1850 & 2100 & 2300 & 1850 & 2100 & 2300 & 1850 & 2100 & 2300 \\
\hline $\begin{array}{l}\text { Hector } \\
\Delta\end{array}$ & 2073.9 & $\begin{array}{r}2264.1 \\
0.76\end{array}$ & $\begin{array}{r}2357.6 \\
0.47\end{array}$ & 294.7 & $\begin{array}{r}879.6 \\
2.34\end{array}$ & $\begin{array}{r}1766.5 \\
4.43\end{array}$ & 8.17 & $\begin{array}{r}7.77 \\
-0.0016\end{array}$ & $\begin{array}{r}7.50 \\
-0.0014\end{array}$ & 4.1 & $\begin{array}{r}2.2 \\
-0.0076\end{array}$ & $\begin{array}{r}1.4 \\
-0.0040\end{array}$ & 6.2 & $\begin{array}{r}3.3 \\
-0.0116\end{array}$ & $\begin{array}{r}2.1 \\
-0.006\end{array}$ \\
\hline $\begin{array}{l}\text { CMIP5 } \\
\Delta\end{array}$ & 1997.57 & $\begin{array}{r}2163.16 \\
0.66\end{array}$ & $\begin{array}{r}2298.89 \\
0.68\end{array}$ & 290.47 & $\begin{array}{r}930.92 \\
2.56\end{array}$ & $\begin{array}{r}1965.23 \\
5.17\end{array}$ & 8.16 & $\begin{array}{r}7.73 \\
-0.0011\end{array}$ & $\begin{array}{r}7.45 \\
-0.0014\end{array}$ & 3.75 & $\begin{array}{r}2.00 \\
-0.0070\end{array}$ & $\begin{array}{r}1.36 \\
-0.0032\end{array}$ & 5.77 & $\begin{array}{r}3.02 \\
-0.0110\end{array}$ & $\begin{array}{r}2.04 \\
-0.0049\end{array}$ \\
\hline
\end{tabular}

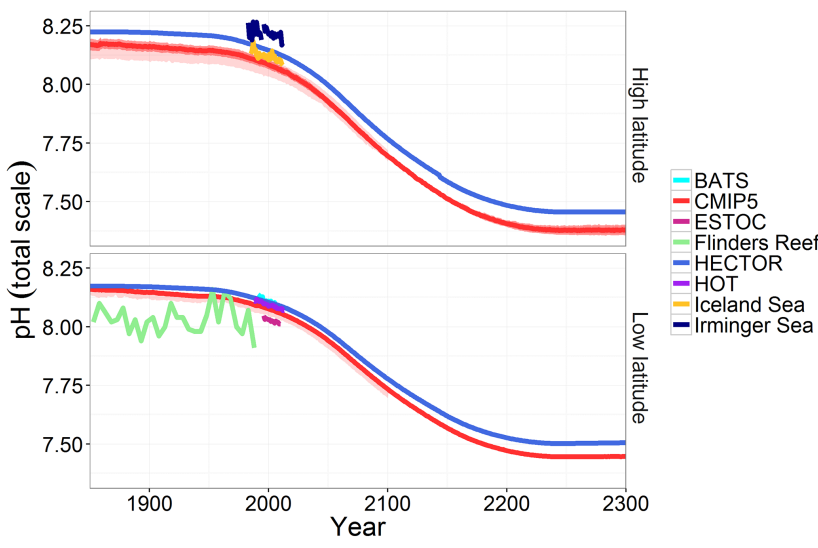

Figure 4. $\mathrm{pH}$ for high- (top) and low-latitude (bottom) surface ocean under RCP 8.5: Hector (blue), CMIP5 median, standard deviation, and model range (red, $n=13(1850-2100)$ and $n=2 ; 2101-2300)$, as well as observations from BATS (teal), ESTOC (pink), HOT (purple) Flinders Reef (green), Iceland Sea (yellow), and Irminger Sea (navy).

in $\mathrm{pH}\left(-0.0017 \mathrm{yr}^{-1}\right)$ compared to observations (Table 6). Other observations in the North Pacific show surface changes of $\mathrm{pH}$ up to 0.06 units between 1991 and 2006 with an average rate of $-0.0017 \mathrm{yr}^{-1}$ (Byrne et al., 2010). Recent work suggests that the North Atlantic absorbed $50 \%$ more anthropogenic $\mathrm{CO}_{2}$ in the last decade compared to the previous decade, decreasing surface $\mathrm{pH}$ by 0.0021 (Woosley et al., 2016). Under RCP 8.5, Hector projects a decrease in lowlatitude $\mathrm{pH}$ of 8.17 in 1850 to 7.77 in 2100 and down to 7.5 by 2300, similar to CMIP5 (Table 5). At approximately 2050, atmospheric $\left[\mathrm{CO}_{2}\right]$ is twice the preindustrial concentrations, corresponding to a decrease in $\mathrm{pH}$ to 7.96 . Shortly after this doubling, $\mathrm{pH}$ values are well outside the natural variability found in Flinders Reef.

Figure 5 illustrates the high- and low-latitude surface $\Omega_{\mathrm{Ar}}$. We only highlight $\Omega_{\mathrm{Ar}}$, as $\Omega_{\mathrm{Ca}}$ is similar to that of $\Omega_{\mathrm{Ar}}$. As with $\mathrm{pH}$, Hector is slightly higher than the CMIP5 $\Omega_{\mathrm{Ar}}$

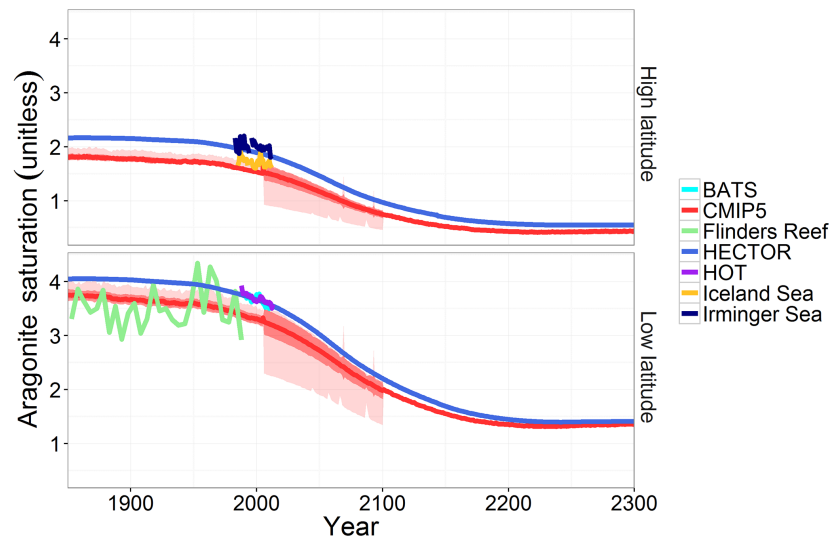

Figure 5. Aragonite saturation $\left(\Omega_{\mathrm{Ar}}\right)$ for high- (top) and lowlatitude (bottom) surface ocean under RCP 8.5: Hector (blue), CMIP5 median, standard deviation, and model range (red, $n=10$ (1850-2100) and $n=2 ; 2101-2300)$, as well as observations from BATS (teal), HOT (purple), and Flinders Reef (green).

median but closer to the observational record. Hector accurately simulates the change in $\Omega_{\mathrm{Ar}}\left(-0.0090 \mathrm{yr}^{-1}\right)$ compared to observations (Table 6). Repeated oceanographic surveys in the Pacific Ocean have observed an average $0.34 \% \mathrm{yr}^{-1}$ decrease in the saturation state of surface seawater with respect to aragonite and calcite over a 14-year period (19912005; Feely et al., 2012); the average decrease in Hector is between 0.19 and $0.25 \% \mathrm{yr}^{-1}$. Saturation levels of $\Omega_{\mathrm{Ar}} \mathrm{de}-$ crease rapidly over the next 100 years in both high and low latitude. Hector accurately captures the decline in saturation states with low RMSE values for $\Omega_{\mathrm{Ar}}$. Under RCP 8.5 , Hector projects that low-latitude $\Omega_{\text {Ar }}$ will decrease to 2.2 by 2100 and down to 1.4 by 2300 . The high-latitude oceans will be undersaturated with respect to aragonite by 2100 and will drop down to 0.7 by 2300 .

Lastly, Fig. 6 highlights $\mathrm{pH}$ and $\Omega_{\text {Ar }}$ projections under all four RCPs from 1850 to 2300 . Over the last 20 years, both $\mathrm{pH}$ and $\Omega_{\mathrm{Ar}}$ have declined sharply and will continue to decline 
Table 6. Trends and standard error for the carbonate system taken from Bates et al. (2014) and values calculated from Hector and CMIP5.

\begin{tabular}{lrrrrr}
\hline & Length of record & $\mathrm{DIC}\left(\mu \mathrm{mol} \mathrm{kg}{ }^{-1} \mathrm{yr}^{-1}\right)$ & $p \mathrm{CO}_{2}\left(\mu \mathrm{atm} \mathrm{yr}{ }^{-1}\right)$ & $\mathrm{pH}\left(\mathrm{yr}^{-1}\right)$ & $\Omega_{\mathrm{Ar}}\left(\mathrm{yr}^{-1}\right)$ \\
\hline BATS & $1983-2014$ & $1.37 \pm 0.07$ & $1.69 \pm 0.11$ & $-0.0017 \pm 0.0001$ & $-0.0095 \pm 0.0007$ \\
HOT & $1988-2014$ & $1.78 \pm 0.12$ & $1.72 \pm 0.09$ & $-0.0016 \pm 0.0001$ & $-0.0084 \pm 0.0011$ \\
ESTOC & $1995-2014$ & $1.09 \pm 0.10$ & $1.92 \pm 0.24$ & $-0.0018 \pm 0.0002$ & $-0.0115 \pm 0.0023$ \\
Iceland Sea & $1983-2014$ & $1.22 \pm 0.27$ & $1.29 \pm 0.36$ & $-0.0014 \pm 0.0005$ & $-0.0018 \pm 0.0027$ \\
Irminger Sea & $1983-2014$ & $1.62 \pm 0.35$ & $2.37 \pm 0.49$ & $-0.0026 \pm 0.0006$ & $-0.0080 \pm 0.0040$ \\
Hector & $1988-2014$ & 0.90 & 1.82 & -0.0017 & -0.0089 \\
CMIP5 & $1988-2014$ & 0.68 & 1.77 & -0.0018 & -0.0074 \\
\hline
\end{tabular}

under RCP 4.5, 6.0 and 8.5, outside of their preindustrial and present-day values. These RCPs represent a range of possible future scenarios, with ocean $\mathrm{pH}$ varying between 8.15 and 7.46 for the high latitude and $\Omega_{\mathrm{Ar}}$ varying between 1.94 and 0.60 . High-latitude $\Omega_{\mathrm{Ar}}$ saturation levels presently are much lower than the low latitude and reach undersaturation before the end of the century. Even under a best-case scenario, RCP 2.6, low-latitude $\mathrm{pH}$ will drop to 8.07 by 2100 and to 8.12 by 2300 , with $\Omega_{\mathrm{Ar}}$ saturation states remaining well outside of present-day values.

\subsection{Model parameter sensitivity}

Parametric sensitives are different between $\left[\mathrm{H}^{+}\right]$and $\Omega_{\mathrm{Ar}}$. We use $\left[\mathrm{H}^{+}\right]$to highlight changes in $\mathrm{pH}$, as $\mathrm{pH}=-\log \left[\mathrm{H}^{+}\right]$. In the near term (from 2005 to 2100) the calculation of $\mathrm{pH}$ is sensitive to a combination of parameters, ocean circulation, beta (terrestrial $\mathrm{CO}_{2}$ fertilization), and wind stress, while on longer timescales (to 2300 ) $\left[\mathrm{H}^{+}\right]$is most sensitive to changes in $Q_{10}$ (terrestrial respiration temperature response) and ocean circulation (Table 7). Global $\Omega_{\mathrm{Ar}}$ is most sensitive to changes in salinity in both the near and long term. Similar to $\left[\mathrm{H}^{+}\right], \Omega_{\mathrm{Ar}}$ becomes more sensitive to changes in $Q_{10}$ in the long term.

\section{Discussion}

The marine carbonate system is projected to undergo significant changes under the RCPs. $p \mathrm{CO}_{2}$ and DIC are increasing rapidly as atmospheric $\left[\mathrm{CO}_{2}\right]$ continues to rise under RCP 4.5, 6.0, and 8.5, while $\mathrm{pH}$ and $\Omega_{\mathrm{Ar}}$ are decreasing rapidly outside of observations and are projected to continue to decrease under all scenarios (Fig. 6). Only under RCP 2.6 do $\mathrm{pH}$ and $\Omega_{\mathrm{Ar}}$ values begin to increase towards present-day values. A lowering of $\Omega_{\mathrm{Ar}}$ from approximately 4.0 to 3.0 is predicted to lead to significant reductions in calcification rates in tropical reefs (Kleypas et al., 1999; Silverman et al., 2009). By the end of the 21 st century, low-latitude ocean $\Omega_{\mathrm{Ar}}$ will drop below 3.0, well outside of the preindustrial values of $\Omega_{\mathrm{Ar}}>3.5$, and high-latitude ocean $\Omega_{\mathrm{Ar}}$ is close to undersaturation $(\Omega<1$; Fig. 6). These results agree with other studies that investigated changes to the carbonate system (Roy
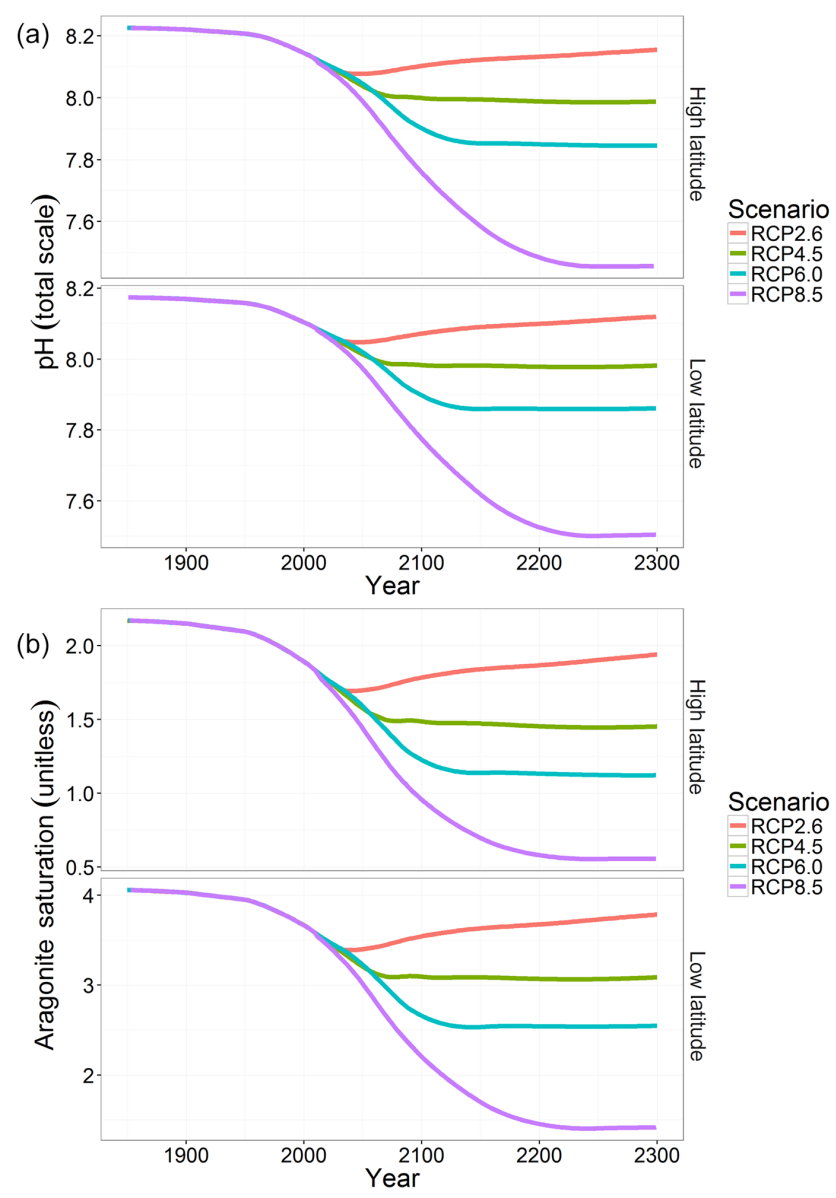

Figure 6. High- and low-latitude (a) $\mathrm{pH}$ and (b) aragonite saturation $\left(\Omega_{\mathrm{Ar}}\right)$ time series for Hector from 1850-2300 for RCP 2.6 (red), RCP 4.5 (green), RCP 6.0 (teal), and RCP 8.5 (purple). Note that even under a strongly mitigated scenario (RCP 2.6), both $\Omega_{\mathrm{Ar}}$ and $\mathrm{pH}$ at 2300 are still lower than preindustrial values.

et al., 2015; Ricke et al., 2013). With seasonal variations in the $\Omega_{\mathrm{Ar}}$ saturation levels accounted for, the time of undersaturation may move forward by up to $17 \pm 10$ years (Sasse et al., 2015). Due to Hector's time step of 1 year, we may be overestimating the time when ocean acidification reaches a critical threshold. We also note that other factors such as 
Table 7. Percentage change from reference (RCP 8.5) for two Hector outputs, (a) global $\left[\mathrm{H}^{+}\right]$and (b) global $\Omega_{\mathrm{Ar}}$, for a $\pm 10 \%$ change in eight model parameters. Results are shown for three years: 2005, 2100 , and 2300 .

\begin{tabular}{|c|c|c|c|}
\hline \multicolumn{4}{|l|}{ (a) } \\
\hline Year & Parameter & $+10 \%$ change & $-10 \%$ change \\
\hline 2005 & Albedo & 0.13 & 0.00 \\
\hline 2100 & & 0.59 & 0.00 \\
\hline 2300 & & 0.00 & -0.31 \\
\hline 2005 & Beta (terrestrial $\mathrm{CO}_{2}$ & 0.63 & -0.50 \\
\hline 2100 & fertilization) & 1.78 & -1.78 \\
\hline 2300 & & 1.56 & -1.88 \\
\hline 2005 & Ocean circulation $\left(T_{\mathrm{T}}\right)$ & 0.76 & -0.76 \\
\hline 2100 & & 2.37 & -1.78 \\
\hline 2300 & & 2.81 & -3.44 \\
\hline 2005 & $Q_{10}$ (terrestrial respiration & -0.13 & 0.13 \\
\hline 2100 & temperature response) & -0.59 & 1.18 \\
\hline 2300 & & -3.13 & 3.44 \\
\hline 2005 & Salinity & -0.88 & 1.51 \\
\hline 2100 & & 0.59 & 0.59 \\
\hline 2300 & & 1.88 & -1.25 \\
\hline 2005 & Climate sensitivity & -0.13 & 0.13 \\
\hline 2100 & & -0.59 & 0.43 \\
\hline 2300 & & -2.5 & 2.50 \\
\hline 2005 & Surface ocean & 0.00 & 0.00 \\
\hline 2100 & temperature & 0.00 & 0.59 \\
\hline 2300 & & 0.62 & 0.31 \\
\hline 2005 & Wind stress & -0.38 & 0.63 \\
\hline 2100 & & -0.59 & 1.78 \\
\hline 2300 & & -1.25 & 1.25 \\
\hline \multicolumn{4}{|l|}{ (b) } \\
\hline Year & Parameter & $+10 \%$ change & $-10 \%$ change \\
\hline 2005 & Albedo & 0.01 & -0.00 \\
\hline 2100 & & 0.01 & -0.01 \\
\hline 2300 & & -0.00 & 0.00 \\
\hline 2005 & Beta (terrestrial $\mathrm{CO}_{2}$ & 0.38 & -0.40 \\
\hline 2100 & fertilization) & 1.33 & -1.34 \\
\hline 2300 & & 1.38 & -1.35 \\
\hline 2005 & Ocean circulation & 0.41 & -0.45 \\
\hline 2100 & $\left(T_{\mathrm{T}}\right)$ & 1.01 & -1.05 \\
\hline 2300 & & 1.48 & -1.55 \\
\hline 2005 & $Q_{10}$ (terrestrial respiration & -0.09 & 0.10 \\
\hline 2100 & temperature response) & -0.87 & 0.95 \\
\hline 2300 & & -2.40 & 3.00 \\
\hline 2005 & Salinity & 3.80 & -4.28 \\
\hline 2100 & & 5.60 & -5.89 \\
\hline 2300 & & 7.17 & -7.18 \\
\hline 2005 & Climate sensitivity & 0.07 & -0.07 \\
\hline 2100 & & 0.55 & -0.56 \\
\hline 2300 & & 0.43 & -0.27 \\
\hline 2005 & Surface ocean & 2.07 & -1.99 \\
\hline 2100 & temperature & 2.41 & -2.29 \\
\hline 2300 & & 2.43 & -2.27 \\
\hline 2005 & Wind stress & -0.18 & 0.25 \\
\hline 2100 & & -0.65 & 0.88 \\
\hline 2300 & & -1.13 & 0.88 \\
\hline
\end{tabular}

eutrophication, river discharge, and upwelling will likely increase the probability that coastal regions will experience the effects of ocean acidification sooner than the projected openocean values in Hector (Ekstrom et al., 2015).

Using $\left[\mathrm{H}^{+}\right]$as a proxy for $\mathrm{pH}$, we find that $\left[\mathrm{H}^{+}\right]$is sensitive to $Q_{10}$ and ocean circulation. Changes in $Q_{10}$ (the respiration temperature response) are responsible for the release of carbon on land. Uncertainties in the land carbon cycle have been attributed to uncertainties in future $\mathrm{CO}_{2}$ projections within the CMIP5 models (Friedlingstein et al., 2014). Therefore, uncertainties in the land carbon cycle will also have implications for the marine carbonate system. A $10 \%$ change in the thermohaline circulation parameter $(\mathrm{Tt}$ in Fig. 1), representing a portion of the high latitude to deep ocean circulation, results in $\sim 3 \%$ change in $\left[\mathrm{H}^{+}\right]$. The dynamics of ocean uptake of $\mathrm{CO}_{2}$ are strongly dependent on this circulation of $\mathrm{CO}_{2}$-laden waters from the surface ocean to depth. CMIP5 models project a weakening in the Atlantic meridional overturning circulation by an average of $36 \%$ under RCP 8.5 by 2100 (Cheng et al., 2013). Therefore, changes in ocean circulation may have implications for the marine carbonate system, influencing the ocean $\mathrm{pH}$. We also find that the high-latitude surface ocean is more sensitive to parameter changes than the low-latitude surface ocean. The high-latitude box makes up $15 \%$ of the global oceans in Hector, and therefore changes in the same size are more easily felt in the high-latitude box compared to the low-latitude box. This may have direct implications on future marine carbonate projections.

Global $\Omega_{\mathrm{Ar}}$ saturation levels are most sensitive to changes in salinity. Salinity is used to calculate $\left[\mathrm{Ca}^{2+}\right]$ and total boron (Appendix B). Typically the carbonate system is normalized to changes in salinity to understand the chemical changes within the system; instead, we show that $\Omega_{\mathrm{Ar}}$ may be sensitive to not only future changes in atmospheric $\left[\mathrm{CO}_{2}\right]$ but also changes in precipitation and evaporation. This may be important, as studies suggest significant changes in precipitation patterns under a changing climate (Held and Soden, 2006; Liu and Allan, 2013).

\section{Conclusions}

We developed a simple, open-source, object-oriented carboncycle climate model, Hector, that reliably reproduces the median of the CMIP5 climate variables (Hartin et al., 2015). The ocean component presented in this study calculates the upper ocean carbonate system $\left(p \mathrm{CO}_{2}, \mathrm{DIC}, \mathrm{pH}, \Omega_{\mathrm{Ar}}, \Omega_{\mathrm{Ca}}\right)$. Under all four RCPs, $\mathrm{pH}$ and $\Omega_{\mathrm{Ar}}$ decrease significantly outside of their preindustrial values matching both observations and CMIP5. In the near future the open-ocean and coral reef communities are likely to experience $\mathrm{pH}$ and carbonate saturation levels unprecedented in the last 2 million years (Hönisch et al., 2009). 
This study is timely because the CMIP5 archive includes a large suite of ESMs that contained dynamic biogeochemistry, allowing us to study future projections of the marine carbon cycle. Rather than running the ESMs, we can use Hector to quickly emulate the global CMIP5 median for projection studies under different emission pathways and sensitivity analyses of the marine carbonate system. Within this study we find that numerous parameters influence $\left[\mathrm{H}^{+}\right]$and $\Omega_{\mathrm{Ar}}$, with both being sensitive to $Q_{10}$. Due to Hector's simplistic nature and fast execution times, Hector has the potential to be a critical tool to the decision-making, scientific, and integrated assessment communities, allowing for further understanding of future changes to the marine carbonate system.

\section{Data availability}

Hector is freely available at https://github.com/JGCRI/ hector. The specific Hector v1.1 referenced in this paper is available at https://github.com/JGCRI/hector/releases/tag/ v1.1. 


\section{Appendix A: Model description - carbon cycle}

The carbon component in Hector contains three carbon reservoirs: a single well-mixed atmosphere, a land component, and an ocean component. The change in atmospheric carbon is a function of the anthropogenic emissions $\left(F_{\mathrm{A}}\right)$, land-use change emissions $\left(F_{\mathrm{LC}}\right)$, and atmosphere-ocean $\left(F_{\mathrm{O}}\right)$ and atmosphere-land $\left(F_{\mathrm{L}}\right)$ carbon fluxes. The default model time step is 1 year.

$\frac{\mathrm{dC}_{\mathrm{atm}}(t)}{\mathrm{d} t}=F_{\mathrm{A}}(t)+F_{\mathrm{LC}}(t)-F_{\mathrm{O}}(t)-F_{\mathrm{L}}(t)$

The terrestrial cycle in Hector contains vegetation, detritus, and soil, all linked to each other and the atmosphere by first-order differential equations. Vegetation net primary production is a function of atmospheric $\mathrm{CO}_{2}$ and temperature. Carbon flows from the vegetation to detritus to soil and loses fractions of carbon to heterotrophic respiration on the way. An "earth" pool debits carbon emitted as anthropogenic emissions, allowing a continual mass-balance check across the entire carbon cycle. Atmosphere-land fluxes at time $t$ are calculated by

$F_{\mathrm{L}}(t)=\sum_{i=1}^{n} \mathrm{NPP}_{i}(t)-\mathrm{RH}_{i}(t)$

where NPP is the net primary production and RH is the heterotrophic respiration summed over user-specified $n$ groups (i.e., latitude bands, political units, or biomes; Hartin et al 2015).

\section{Appendix B: Ocean carbonate chemistry}

The ocean's inorganic carbon system is solved via a series of equations modified from Zeebe and Wolf-Gladrow (2001). TA and DIC are used to calculate the other variables of the carbonate system:

$$
\begin{aligned}
\text { DIC } & \times\left(\frac{\mathrm{K}_{1}}{\left[\mathrm{H}^{+}\right]}+2 \frac{\mathrm{K}_{1} \mathrm{~K}_{2}}{\left[\mathrm{H}^{+}\right]^{2}}\right) \\
& =\left(\mathrm{TA}-\frac{\mathrm{K}_{B} \mathrm{~B}_{T}}{\mathrm{~K}_{B}+\left[\mathrm{H}^{+}\right]}-\frac{\mathrm{K}_{W}}{\left[\mathrm{H}^{+}\right]}+\left[\mathrm{H}^{+}\right]\right) \\
& \times\left(1+\frac{\mathrm{K}_{1}}{\left[\mathrm{H}^{+}\right]}+\frac{\mathrm{K}_{1} \mathrm{~K}_{2}}{\left[\mathrm{H}^{+}\right]^{2}}\right) .
\end{aligned}
$$

This equation results in a higher-order polynomial equation for $\mathrm{H}^{+}$, in which the roots (one positive, four negative) are solved for. Once $\mathrm{H}^{+}$is solved for, $\mathrm{pH}, p \mathrm{CO}_{2}, \mathrm{HCO}_{3}^{-}$, and $\mathrm{CO}_{3}^{2-}$ can be determined. We ignore the nonideality of $\mathrm{CO}_{2}$ in air and therefore use the partial pressure of $\mathrm{CO}_{2}$ instead of the fugacity of $\mathrm{CO}_{2}$. Fugacity is slightly lower by $\sim 0.3 \%$ compared to $p \mathrm{CO}_{2}$ (Riebesell et al., 2009; Sarmiento and Gruber, 2006).

$$
\begin{aligned}
{\left[\mathrm{CO}_{2}^{*}\right] } & =\frac{\mathrm{DIC}}{\left(1+\frac{\mathrm{K}_{1}}{\left[\mathrm{H}^{+}\right]}+\frac{\mathrm{K}_{1} K_{2}}{\left[\mathrm{H}^{+}\right]^{2}}\right)} \\
p \mathrm{CO}_{2} & =\frac{\left[\mathrm{CO}_{2}^{*}\right]}{\mathrm{K}_{\mathrm{H}}} \\
{\left[\mathrm{HCO}_{3}^{-}\right] } & =\frac{\mathrm{DIC}}{\left(1+\frac{\left[\mathrm{H}^{+}\right]}{\mathrm{K}_{1}}+\frac{\mathrm{K}_{2}}{\left[\mathrm{H}^{+}\right]}\right)} \\
{\left[\mathrm{CO}_{3}^{2-}\right] } & =\frac{\mathrm{DIC}}{\left(1+\frac{\left[\mathrm{H}^{+}\right]}{\mathrm{K}_{2}}+\frac{\left[\mathrm{H}^{+}\right]^{2}}{\mathrm{~K}_{2}}\right)} \\
\mathrm{K}_{1} & =\frac{\left[\mathrm{H}^{+}\right]\left[\mathrm{HCO}_{3}^{-}\right]}{\left[\mathrm{CO}_{2}\right]} \\
\mathrm{K}_{2} & =\frac{\left[\mathrm{H}^{+}\right]\left[\mathrm{CO}_{3}^{2-}\right]}{\left[\mathrm{HCO}_{3}^{-}\right]}
\end{aligned}
$$

$\mathrm{K}_{1}$ and $\mathrm{K}_{2}$ are the first and second acidity constants of carbonic acid from Mehrbach et al. (1973) and refit by Lueker et al. (2000).

$\mathrm{K}_{\mathrm{B}}=\frac{\left[\mathrm{H}^{+}\right]\left[B(\mathrm{OH})_{4}^{-}\right]}{\left[B(\mathrm{OH})_{3}\right]}$

$\mathrm{K}_{\mathrm{B}}$ is the dissociation constant of boric acid from DOE (1994).

$B=416.0 \times \frac{S}{35.0}$

Total boron is from DOE (1994)

$\mathrm{K}_{\mathrm{W}}=\frac{\left[\mathrm{H}^{+}\right]}{\left[\mathrm{OH}^{-}\right]}$

$\mathrm{K}_{\mathrm{W}}$ is the dissociation constant of water from Millero (1995).

$K_{\text {sp }}=\left[\mathrm{Ca}^{2+}\right] \times\left[\mathrm{CO}_{3}^{2-}\right]$

$\mathrm{K}_{\mathrm{sp}}$ of aragonite and calcite is calculated from Mucci (1983).

For those equations with multiple coefficients:

1. $\mathrm{K}_{\mathrm{H}}$ and $\mathrm{K}_{0}$ are similar equations calculating Henry's constant or the solubility of $\mathrm{CO}_{2}$, but they return different units (mol kg${ }^{-1} \mathrm{~atm}^{-1}$ and $\mathrm{mol} \mathrm{L}^{-1} \mathrm{~atm}^{-1}$; see Weiss, 1974, for equations and coefficients). $\mathrm{K}_{\mathrm{H}}$ is used to solve $p \mathrm{CO}_{2}$, while $\mathrm{K}_{0}$ is used to solve air-sea fluxes of $\mathrm{CO}_{2}$.

2. The Schmidt number is taken from Wanninkhof (1992) for coefficients of $\mathrm{CO}_{2}$ in seawater.

3. $\left[\mathrm{Ca}^{2+}\right]\left(\mathrm{mol} \mathrm{kg}^{-1}\right)$ is calculated from Riley and Tongudai (1967). 
Author contributions. C. A. Hartin designed and carried out the experiments. C. A. Hartin, B. Bond-Lamberty, and P. Patel developed the model code. A. Mundra processed the data and prepared the figures. C. A. Hartin prepared the manuscript with contributions from all co-authors.

Acknowledgements. This research is based on work supported by the US Department of Energy. The Pacific Northwest National Laboratory is operated for DOE by Battelle Memorial Institute under contract DE-AC05-76RL01830.

Edited by: C. P. Slomp

Reviewed by: three anonymous referees

\section{References}

Albright, R., Langdon, C., and Anthony, K. R. N.: Dynamics of seawater carbonate chemistry, production, and calcification of a coral reef flat, central Great Barrier Reef, Biogeosciences, 10, 6747-6758, doi:10.5194/bg-10-6747-2013, 2013.

Archer, D., Eby, M., Brovkin, V., Ridgwell, A., Cao, L., Mikolajewicz, U., Caldeira, K., Matsumoto, K., Munhoven, G., Montenegro, A., and Tokos, K.: Atmospheric Lifetime of Fossil Fuel Carbon Dioxide, Annu. Rev. Earth Planet. Sci., 37, 117-134, doi:10.1146/annurev.earth.031208.100206, 2009.

Bates, N. R.: Interannual variability of the oceanic $\mathrm{CO}_{2}$ sink in the subtropical gyre of the North Atlantic Ocean over the last 2 decades, J. Geophys. Res.-Oceans, 112, C09013, doi:10.1029/2006JC003759, 2007.

Bates, N. R., Astor, Y. M., Church, M. J., Currie, K., Dore, J. E., Gonzalez-Davila, M., Lorenzoni, L., Muller-Karger, F., Olafsson, J., and Santana-Casiano, J. M.: A time-series view of changing ocean chemistry due to ocean uptake of anthropogenic $\mathrm{CO}_{2}$ and ocean acidification, Oceanography, 27, 126141, doi:10.5670/oceanog.2014.16, 2014.

Bopp, L., Resplandy, L., Orr, J. C., Doney, S. C., Dunne, J. P., Gehlen, M., Halloran, P., Heinze, C., Ilyina, T., Séférian, R., Tjiputra, J., and Vichi, M.: Multiple stressors of ocean ecosystems in the 21st century: projections with CMIP5 models, Biogeosciences, 10, 6225-6245, doi:10.5194/bg-10-6225-2013, 2013.

Byrne, R. H., Mecking, S., Feely, R. A., and Liu, X.: Direct observations of basin-wide acidification of the North Pacific Ocean, Geophys. Res. Lett., 37, L02601, doi:10.1029/2009GL040999, 2010.

Caldeira, K., Jain, A. K., and Hoffert, M. I.: Climate Sensitivity Uncertainty and the Need for Energy Without $\mathrm{CO}_{2}$ Emission, Science, 299, 2052-2054, doi:10.1126/science.1078938, 2003.

Cheng, W., Chiang, J. C. H., and Zhang, D.: Atlantic Meridional Overturning Circulation (AMOC) in CMIP5 Models: RCP and Historical Simulations, J. Climate, 26, 7187-7197, doi:10.1175/JCLI-D-12-00496.1, 2013.

Cooley, S. R. and Doney, S. C.: Anticipating ocean acidification's economic consequences for commercial fisheries, Environ. Res. Lett., 4, 024007, doi:10.1088/1748-93261/4/2/024007, 2009.
Davidson, E. A. and Janssens, I. A.: Temperature sensitivity of soil carbon decomposition and feedbacks to climate change, Nature, 440, 165-173, 2006.

Dickson, A. G. and Millero, F. J.: A comparison of the equilibrium constants for the dissociation of carbonic acid in seawater media, Deep-Sea Res. Pt. A, 34, 1733-1743, doi:10.1016/01980149(87)90021-5, 1987.

DOE: Handbook of methods for the analysis of the various parameters of the carbon dioxide system in sea water, edited by: Dickson, A. G. and Goyet, C., ORNL/CDIAC-74, 1994.

Doney, S. C.: The Growing Human Footprint on Coastal and Open-Ocean Biogeochemistry, Science, 328, 1512-1516, doi:10.1126/science.1185198, 2010.

Dore, J. E., Lukas, R., Sadler, D. W., Church, M. J., and Karl, D. M.: Physical and biogeochemical modulation of ocean acidification in the central North Pacific, P. Natl. Acad. Sci. USA, 106, 1223512240, doi:10.1073/pnas.0906044106, 2009.

Eglinton, T. I. and Repeta, D. J.: Organic Matter in the Contemporary Ocean, Treatise on Geochemistry, edited by: Holland, H. D. and Turekian, K. K., Elsevier, Amsterdam, 2004.

Ekstrom, J. A., Suatoni, L., Cooley, S. R., Pendleton, L. H., Waldbusser, G. G., Cinner, J. E., Ritter, J., Langdon, C., van Hooidonk, R., Gledhill, D., Wellman, K., Beck, M. W., Brander, L. M., Rittschof, D., Doherty, C., Edwards, P. E. T., and Portela, R.: Vulnerability and adaptation of US shellfisheries to ocean acidification, Nature Climate Change, 5, 207-214, doi:10.1038/nclimate2508, 2015.

Fabry, V. J., Seibel, B. A., Feely, R. A., and Orr, J. C.: Impacts of ocean acidification on marine fauna and ecosystem processes, ICES J. Mar. Sci., 65, 414-432, doi:10.1093/icesjms/fsn048, 2008.

Feely, R. A., Sabine, C. L., Lee, K., Berelson, W., Kleypas, J., Fabry, V. J., and Millero, F. J.: Impact of Anthropogenic $\mathrm{CO}_{2}$ on the $\mathrm{CaCO}_{3}$ System in the Oceans, Science, 305, 362-366, doi:10.1126/science.1097329, 2004.

Feely, R. A., Doney, S. C., and Cooley, S. R.: Ocean acidification: present conditions and future changes in a high- $\mathrm{CO}_{2}$ world, Oceanography, 22, 36-47, doi:10.5670/oceanog.2009.95, 2009.

Feely, R. A., Sabine, C. L., Byrne, R. H., Millero, F. J., Dickson, A. G., Wanninkhof, R., Murata, A., Miller, L. A., and Greeley, D.: Decadal changes in the aragonite and calcite saturation state of the Pacific Ocean, Global Biogeochem. Cy., 26, GB3001, doi:10.1029/2011GB004157, 2012.

Friedlingstein, P., Meinshausen, M., Arora, V. K., Jones, C. D., Anav, A., Liddicoat, S. K., and Knutti, R.: Uncertainties in CMIP5 Climate Projections due to Carbon Cycle Feedbacks, J. Climate, 27, 511-526, doi:10.1175/JCLI-D-12-00579.1, 2014.

Fry, C. H., Tyrrell, T., Hain, M. P., Bates, N. R., and Achterberg, E. P.: Analysis of global surface ocean alkalinity to determine controlling processes, Mar. Chem., 174, 46-57, doi:10.1016/j.marchem.2015.05.003, 2015.

Gehlen, M., Séférian, R., Jones, D. O. B., Roy, T., Roth, R., Barry, J., Bopp, L., Doney, S. C., Dunne, J. P., Heinze, C., Joos, F., Orr, J. C., Resplandy, L., Segschneider, J., and Tjiputra, J.: Projected $\mathrm{pH}$ reductions by 2100 might put deep North Atlantic biodiversity at risk, Biogeosciences, 11, 6955-6967, doi:10.5194/bg-116955-2014, 2014.

Glotter, M., Pierrehumbert, R., Elliott, J., Matteson, N., and Moyer, E.: A simple carbon cycle representation for economic and policy 
analyses, Climatic Change, 126, 319-335, doi:10.1007/s10584014-1224-y, 2014.

González-Dávila, M., Santana-Casiano, J. M., and GonzálezDávila, E. F.: Interannual variability of the upper ocean carbon cycle in the northeast Atlantic Ocean, Geophys. Res. Lett., 34, L07608, doi:10.1029/2006GL028145, 2007.

Hansell, D. A. and Carlson, C. A.: Marine dissolved organic matter and the carbon cycle, Oceanography, 14, 41-49, 2001.

Hartin, C. A., Patel, P., Schwarber, A., Link, R. P., and BondLamberty, B. P.: A simple object-oriented and open-source model for scientific and policy analyses of the global climate system Hector v1.0, Geosci. Model Dev., 8, 939-955, doi:10.5194/gmd8-939-2015, 2015.

Held, I. M. and Soden, B. J.: Robust Responses of the Hydrological Cycle to Global Warming, J. Climate, 19, 5686-5699, doi:10.1175/JCLI3990.1, 2006.

Hönisch, B., Hemming, N. G., Archer, D., Siddall, M., and McManus, J. F.: Atmospheric Carbon Dioxide Concentration Across the Mid-Pleistocene Transition, Science, 324, 15511554, doi:10.1126/science.1171477, 2009.

IPCC: Climate Change 2013: The Physical Science Basis, in: Contribution of Working Group I to the Fifth Assessment Report of the Intergovernmental Panel on Climate Change, edited by: Stocker, T. F., Qin, D., Plattner, G.-K., Tignor, M., Allen, S. K., Boschung, J., Nauels, A., Xia, Y., Bex, V., and Midgley, P. M., Cambridge University Press, Cambridge, United Kindom and New York, NY, USA, 1535 pp., 2013.

Irvine, P. J., Sriver, R. L., and Keller, K.: Tension between reducing sea-level rise and global warming through solarradiation management, Nature Climate Change, 2, 97-100, doi:10.1038/nclimate1351, 2012.

Joos, F., Plattner, G.-K., Stocker, T. F., Marchal, O., and Schmittner, A.: Global Warming and Marine Carbon Cycle Feedbacks on Future Atmospheric $\mathrm{CO}_{2}$, Science, 284, 464-467, doi:10.1126/science.284.5413.464, 1999.

Key, R. M., Kozyr, A., Sabine, C. L., Lee, K., Wanninkhof, R., Bullister, J. L., Feely, R. A., Millero, F. J., Mordy, C., and Peng, T. H.: A global ocean carbon climatology: Results from Global Data Analysis Project (GLODAP), Global Biogeochem. Cy., 18, GB4031, doi:10.1029/2004GB002247, 2004.

Kleypas, J. A., Buddemeier, R. W., Archer, D., Gattuso, J.-P., Langdon, C., and Opdyke, B. N.: Geochemical Consequences of Increased Atmospheric Carbon Dioxide on Coral Reefs, Science, 284, 118-120, doi:10.1126/science.284.5411.118, 1999.

Knox, F. and McElroy, M. B.: Changes in Atmospheric $\mathrm{CO}_{2}$ : Influence of the Marine Biota at High Latitude, J. Geophys. Res., 89, 4629-4637, doi:10.1029/JD089iD03p04629, 1984.

Kump, L. R., Bralower, T. R., and Ridgwell, A. J.: Ocean Acidification in Deep Time, Oceanography, 22, 94-107, 2009.

Lenton, T. M.: Land and ocean carbon cycle feedback effects on global warming in a simple Earth system model, Tellus B, 52, 1159-1188, doi:10.1034/j.1600-0889.2000.01104.x, 2000.

Le Quéré, C., Takahashi, T., Buitenhuis, E. T., Rödenbeck, C., and Sutherland, S. C.: Impact of climate change and variability on the global oceanic sink of $\mathrm{CO}_{2}$, Global Biogeochem. Cy., 24, GB4007, doi:10.1029/2009GB003599, 2010.

Le Quéré, C., Andres, R. J., Boden, T., Conway, T., Houghton, R. A., House, J. I., Marland, G., Peters, G. P., van der Werf, G. R., Ahlström, A., Andrew, R. M., Bopp, L., Canadell, J. G., Ciais,
P., Doney, S. C., Enright, C., Friedlingstein, P., Huntingford, C., Jain, A. K., Jourdain, C., Kato, E., Keeling, R. F., Klein Goldewijk, K., Levis, S., Levy, P., Lomas, M., Poulter, B., Raupach, M. R., Schwinger, J., Sitch, S., Stocker, B. D., Viovy, N., Zaehle, S., and Zeng, N.: The global carbon budget 1959-2011, Earth Syst. Sci. Data, 5, 165-185, doi:10.5194/essd-5-165-2013, 2013.

Lewis, E. and Wallace, D. W. R.: Program Developed for $\mathrm{CO}_{2}$ System Calculations, ORNL/CDIAC-105, Carbon Dioxide Information Analysis Center, Oak Ridge National Laboratory, US Department of Energy, Oak Ridge, Tennessee, 1998.

Liu, C. and Allan, R., P. : Observed and simulated precipitation responses in wet and dry regions 1850-2100, Environ. Res. Lett. 8, 034002, doi:10.1088/1748-9326/8/3/034002, 2013.

Lueker, T. J., Dickson, A. G., and Keeling, C. D.: Ocean $p \mathrm{CO}_{2}$ calculated from dissolved inorganic carbon, alkalinity, and equations for $\mathrm{K} 1$ and $\mathrm{K} 2$; validation based on laboratory measurements of $\mathrm{CO}_{2}$ in gas and seawater at equilibrium, Mar. Chem., 70, 105-119, 2000.

Matear, R. J. and Hirst, A. C.: Climate change feedback on the future oceanic $\mathrm{CO}_{2}$ uptake, Tellus $\mathrm{B}, 51,722-733$, doi:10.1034/j.1600-0889.1999.t01-1-00012.x, 1999.

Mehrbach, C., Culberson, C. H., Hawley, J. E., and Pytkowicz, R. M.: Measurement of the apparent dissociation constants of carbonic acid in seawater at atmospheric perssure, Limnol. Oceanogr., 18, 897-907, 1973.

Millero, F. J.: Thermodynamics of the carbon dioxide system in the oceans, Geochim. Cosmochim. Ac., 59, 661-677, doi:10.1016/0016-7037(94)00354-O, 1995.

Moss, R. H., Edmonds, J. A., Hibbard, K. A., Manning, M. R., Rose, S. K., van Vuuren, D. P., Carter, T. R., Emori, S., Kainuma, M., Kram, T., Meehl, G. A., Mitchell, J. F. B., Nakicenovic, N., Riahi, K., Smith, S. J., Stouffer, R. J., Thomson, A. M., Weyant, J. P., and Wilbanks, T. J.: The next generation of scenarios for climate change research and assessment, Nature, 463, 747-756, doi:10.1038/nature08823, 2010.

Mucci, A.: The solubility of calcite and aragonite in seawater at various salinities, temperatures and at one atmopshere pressure, Am. J. Sci., 283, 781-799, 1983.

Olafsson, J., Olafsdottir, S. R., Benoit-Cattin, A., Danielsen, M., Arnarson, T. S., and Takahashi, T.: Rate of Iceland Sea acidification from time series measurements, Biogeosciences, 6, 6612,668, doi:10.5194/bg-6-2661-2009, 2009.

Olafsson, J., Olafsdottir, S. R., Benoit-Cattin, A., and Takahashi, T.: The Irminger Sea and the Iceland Sea time series measurements of sea water carbon and nutrient chemistry 1983-2008, Earth Syst. Sci. Data, 2, 99-104, doi:10.5194/essd-2-99-2010, 2010.

Orr, J. C., Fabry, V. J., Aumont, O., Bopp, L., Doney, S. C., Feely, R. A., Gnanadesikan, A., Gruber, N., Ishida, A., Joos, F., Key, R. M., Lindsay, K., Maier-Reimer, E., Matear, R., Monfray, P., Mouchet, A., Najjar, R. G., Plattner, G.-K., Rodgers, K. B., Sabine, C. L., Sarmiento, J. L., Schlitzer, R., Slater, R. D., Totterdell, I. J., Weirig, M.-F., Yamanaka, Y., and Yool, A.: Anthropogenic ocean acidification over the twenty-first century and its impact on calcifying organisms, Nature, 437, 681-686, doi:10.1038/nature04095, 2005.

Pelejero, C., Calvo, E., McCulloch, M. T., Marshall, J. F., Gagan, M. K., Lough, J. M., and Opdyke, B. N.: Preindustrial to Modern 
Interdecadal Variability in Coral Reef pH, Science, 309, 22042207, doi:10.1126/science.1113692, 2005.

Pietsch, S. A. and Hasenauer, H.: Evaluatin the self-initialization procedure for large-scale ecosystem models, Glob. Change Biol., 12, 1-12, 2006.

Riahi, K., Rao, S., Krey, V., Cho, C., Chirkov, V., Fischer, G., Kindermann, G., Nakicenovic, N., and Rafaj, P.: RCP 8.5 - A scenario of comparatively high greenhouse gas emissions, Climatic Change, 109, 33-57, doi:10.1007/s10584-011-0149-y, 2011.

Ricciuto, D. M., Davis, K. J., and Keller, K.: A Bayesian calibration of a simple carbon cycle model: The role of observations in estimating and reducing uncertainty, Global Biogeochem. Cy., 22, GB2030, doi:10.1029/2006GB002908, 2008.

Ricke, K. L., Orr, J. C., Schneider, K., and Caldeira, K.: Risks to coral reefs from ocean carbonate chemistry changes in recent earth system model projections, Environ. Res. Lett., 8, 034003, doi:10.1088/1748-9326/8/3/034003, 2013.

Riebesell, U., Zondervan, I., Rost, B., Tortell, P. D., Zeebe, R. E., and Morel, F. M. M.: Reduced calcification of marine plankton in response to increased atmospheric $\mathrm{CO}_{2}$, Nature, 407, 364-367, 2000.

Riebesell, U., Körtzinger, A., and Oschlies, A.: Sensitivities of marine carbon fluxes to ocean change, P. Natl. Acad. Sci. USA, 106, 20602-20609, doi:10.1073/pnas.0813291106, 2009.

Riley, J. P. and Tongudai, M.: The major cation/chlorinity ratios in sea water, Chem. Geol., 2, 263-269, doi:10.1016/00092541(67)90026-5, 1967.

Roy, T., Lombard, F., Bopp, L., and Gehlen, M.: Projected impacts of climate change and ocean acidification on the global biogeography of planktonic Foraminifera, Biogeosciences, 12, 2873-2889, doi:10.5194/bg-12-2873-2015, 2015.

Sabine, C. L., Feely, R. A., Gruber, N., Key, R. M., Lee, K., Bullister, J. L., Wanninkhof, R., Wong, C. S., Wallace, D. W. R., Tilbrook, B., Millero, F. J., Peng, T.-H., Kozyr, A., Ono, T., and Rios, A. F.: The Oceanic Sink for Anthropogenic $\mathrm{CO}_{2}$, Science, 305, 367-371, doi:10.1126/science.1097403, 2004.

Sabine, C. L., Feely, R., Wanninkhof, R., Takahashi, T., Khatiwala, S., and Park, G.-H.: The global ocean carbon cycle, In State of the Climate in 2010, Global Oceans, B. Am. Meteorol. Soc., 92, S100-S108, doi:10.1175/1520-0477-92.6.S1, 2011.

Sarmiento, J. L. and Toggweiler, J. R.: A new model for the role of the oceans in determining atmospheric $\mathrm{PCO}_{2}$, Nature, 308, 621-624, 1984.

Sarmiento, J. L. and Le Quéré, C.: Oceanic Carbon Dioxide Uptake in a Model of Century-Scale Global Warming, Science, 274, 1346-1350, doi:10.1126/science.274.5291.1346, 1996.

Sarmiento, J. L. and Gruber, N.: Ocean Biogeochemical Dynamics, edited by: Press, P. U., Princeton NJ, 2006.

Sasse, T. P., McNeil, B. I., Matear, R. J., and Lenton, A.: Quantifying the influence of $\mathrm{CO}_{2}$ seasonality on future aragonite undersaturation onset, Biogeosciences, 12, 6017-6031, doi:10.5194/bg-12-6017-2015, 2015.
Senior, C. A. and Mitchell, J. F. B.: The time-dependence of climate sensitivity, Geophys. Res. Lett., 27, 2685-2688, doi:10.1029/2000GL011373, 2000.

Siegenthaler, U. and Joos, F.: Use of a simple model for studying oceanic tracer distributions and the global carbon cycle, Tellus B, 44, 186-207, doi:10.1034/j.1600-0889.1992.t01-2-00003.x, 1992.

Silverman, J., Lazar, B., Cao, L., Caldeira, K., and Erez, J.: Coral reefs may start dissolving when atmospheric $\mathrm{CO}_{2}$ doubles, Geophys. Res. Lett., 36, L05606, doi:10.1029/2008GL036282, 2009.

Takahashi, T., Sutherland, S. C., Wanninkhof, R., Sweeney, C., Feely, R. A., Chipman, D. W., Hales, B., Friederich, G., Chavez, F., Sabine, C., Watson, A., Bakker, D. C. E., Schuster, U., Metzl, N., Yoshikawa-Inoue, H., Ishii, M., Midorikawa, T., Nojiri, Y., Körtzinger, A., Steinhoff, T., Hoppema, M., Olafsson, J., Arnarson, T. S., Tilbrook, B., Johannessen, T., Olsen, A., Bellerby, R., Wong, C. S., Delille, B., Bates, N. R., and de Baar, H. J. W.: Climatological mean and decadal change in surface ocean $p \mathrm{CO}_{2}$, and net sea-air $\mathrm{CO}_{2}$ flux over the global oceans, Deep-Sea Res. Pt. II, 56, 554-577, doi:10.1016/j.dsr2.2008.12.009, 2009.

Taylor, K. E., Stouffer, R. J., and Meehl, G. A.: An Overview of CMIP5 and the Experiment Design, B. Am. Meteorol. Soc., 93, 485-498, doi:10.1175/BAMS-D-11-00094.1, 2012.

van Vuuren, D., Elzen, M. J., Lucas, P., Eickhout, B., Strengers, B., Ruijven, B., Wonink, S., and Houdt, R.: Stabilizing greenhouse gas concentrations at low levels: an assessment of reduction strategies and costs, Climatic Change, 81, 119-159, doi:10.1007/s10584-006-9172-9, 2007.

Wanninkhof, R.: Relationship between wind speed and gas exchange over the ocean, J. Geophys. Res.-Oceans, 97, 7373-7382, doi:10.1029/92JC00188, 1992.

Weiss, R. F.: Carbon dioxide in water and seawater: the solubility of a non-ideal gas, Mar. Chem., 2, 203-215, doi:10.1016/03044203(74)90015-2, 1974.

Woosley, R. J., Millero, F. J., and Wanninkhof, R.: Rapid anthropogenic changes in $\mathrm{CO}_{2}$ and $\mathrm{pH}$ in the Atlantic Ocean: 2003-2014, Global Biogeochem. Cy., 30, 70-90, doi:10.1002/2015GB005248, 2016.

Wullschleger, S. D., Post, W. M., and King, A. W.: On the Potential for a $\mathrm{CO}_{2}$ Fertilization Effect in Forests: Estimates of the Biotic Growth Factor, Based on 58 Controlled-Exposure Studies, Biotic Feedbacks in the Global Climate System: Will the Warming Feed the Warming?, edited by: Woodwell, G. M. and Mackenzie, F. T., Oxford University, New York, 1995.

Yates, K. K. and Halley, R. B.: $\mathrm{CO}_{3}^{2-}$ concentration and $p \mathrm{CO}_{2}$ thresholds for calcification and dissolution on the Molokai reef flat, Hawaii, Biogeosciences, 3, 357-369, doi:10.5194/bg-3-3572006, 2006.

Zeebe, R. E. and Wolf-Gladrow, D.: $\mathrm{CO}_{2}$ in Seawater: Equilibrium, Kinetics, Isotopes, Elsevier, Amsterdam, 2001. 